\title{
Nutritional Evaluation and Utilization of Pea Pod Powder for Preparation of Jaggery Biscuits
}

Meenakshi Garg*

Assistant Professor, Food Technology Department, University of Delhi, India

\begin{abstract}
Food industry generates massive waste, which is a concern not only to environment but also loss of valuable biomass. The foremost benefit of industrial waste is that it is available at zero cost and in immense quantities. Pea pods which otherwise are discarded in bins or at finest used for animal feed is exploited for its nutritional benefits in present study. Pea powder formulated was found rich in crude protein, fibre and ash with exceptional good amounts of iron. Composition of powder was $5 \%$ ash, $0.43 \%$ fat, $14.88 \%$ protein, $77.86 \%$ crude fibre, $61.43 \%$ total carbohydrates and $309.11 \mathrm{Kcal}$ energy content The concept of healthy eating is addressed in current analysis whereby, value added biscuits are devised by substituting pea pod powder in place of refined wheat flour at $10 \%, 20 \%$ and $30 \%$ level. Sensory evaluation conducted using a 9-point hedonic scale revealed $20 \%$ level as optimum level of incorporation. Water activity decreased slightly on storage. The biscuits are advantageous for people suffering from lifestyle diseases as these contain high amount of fibre and minerals. In this way peels can also be utilized for human consumption otherwise this important source of nutrients goes wasted.
\end{abstract}

\section{Research Highlights}

a. Food industry waste, pea pods are transformed to powder.

b. Pea pod fibre thus, obtained has high protein, fibre and minerals especially iron

c. Value added biscuits are prepared by substituting wheat flour with pea pod powder at various concentrations

d. Sensory and physical evaluation of biscuits revealed high acceptability

Keywords: Pea pod; Nutritional evaluation; Sensory evaluation; Biscuits; Jaggery

\section{Introduction}

Outsized amount of waste either solid or liquid in nature is being produced by food industry nowadays on regular basis. The unwanted artifacts pose not merely disposable concerns but furthermore massive loss of nutrients. Many studies indicate food-processing waste might have potential for reutilizing into raw useful products or by-products of higher value [1]. Fruit and vegetable waste has been established to stand good source of numerous polyphenols [2-7]. Vegetable waste yet remains unexploited source of phytonutrients in comparison to fruit waste. Carrot peels [8], outer leaves of cabbage have been used to produce antioxidant rich dietary fibre powder [9]. Arora and Camire [10] reported potato peels as dietary fibre supplement in muffins and cookies. Cauliflower by-products incorporation increased not only dietary fibre but also protein content in ready-to-eat snacks [11]. A lot of work has been done on antioxidant properties of tomato peel [1214]. There are many other vegetable waste sources, which are yet to be discovered and utilized like pea pod. India is the second largest producer of green peas next to China [15]. Established upon supposition, $30 \%$ of the total pea weight is owing to pea pods (fresh weight basis). Thus based on India's yearly production of pea, more than 1 million ton of pea pod waste is generated annually alone in India, of which sizeable extent is discarded as waste [16]. Use of pea pod waste for cellulolytic enzyme production), feed for goat bucks [17], ruminants [18-21] has been reported. Literature reveals pea pods have high protein and dietary fibre [22].

Amid gigantic changes in working environments and economics, there is an equal comparable change in lifestyle. The demand for processed food has sky rocketed. Baked products have made their space in Indian kitchen since time immemorial. Baked foods especially biscuits are low in cost; can be stored for long time at room temperature. Consumer today wants to consume food, which can fit into their concept of holistic and healthy eating. Manufacturers and researchers around the globe are working to replace unhealthy ingredients and supplement them with therapeutic value [23-28]. Aim of the present work was to develop pea pod powder and showcase it as a potential source of nutrient. Pea pod powder produced thus is used as a prospective dietary fiber supplement in biscuits with sugar replaced by jaggery to further enhance the nutritive value.

\section{Materials and Methods}

Commercial refined wheat flour (brand Rajdhani Flour Mill Ltd) was purchased from local supermarket (Sanjay Store, Possangipur, New Delhi, India). Peas were purchased from local vegetable market (Azadpur mandi, New Delhi, India). Seeds were removed from pea pods. Pea pods were subjected to standard washing using Veg Fru Wash. Cleaned pods were dried in tray drier (Assembled at Agro Life Science Solutions Pvt Ltd., New Delhi, India) at $65^{\circ} \mathrm{c}$ for $5 \mathrm{hrs} \mathrm{[20].}$

${ }^{*}$ Corresonding author: Meenakshi Garg, Ph.D. Assistant Professor, Food Technology Department, University of Delhi, India, Tel: 237374446-111; Email: meenagargbcas@gmail.com

Received October 15, 2015; Accepted October 15, 2015; Published November 15,2015

Citation: Garg M (2015) Nutritional Evaluation and Utilization of Pea Pod Powder for Preparation of Jaggery Biscuits. J Food Process Technol 6: 522 doi:10.4172/2157-7110.1000522

Copyright: (c) 2015 Garg M. This is an open-access article distributed under the terms of the Creative Commons Attribution License, which permits unrestricted use, distribution, and reproduction in any medium, provided the original author and source are credited. 
Citation: Garg M (2015) Nutritional Evaluation and Utilization of Pea Pod Powder for Preparation of Jaggery Biscuits. J Food Process Technol 6: 522. doi:10.4172/2157-7110.1000522

\section{Preparation of pea pod powder}

Pods after drying were subjected to grinding (Model MXAC555, Panasonic India) to obtain fine pea pod powder.

\section{Composition of biscuit flour}

Blends of pea pod powder with refined wheat flours were prepared by combinations of 90:10, 90:20 and 90:30 of refined wheat flour with pea pod powder.

\section{Preparation of biscuits}

Biscuits were prepared from composite flours of wheat flour, pea pod powder and other ingredients such as shortenings, jaggery, salt and sodium bicarbonate (Table 1). Ingredients were weighed using an electric balance (Model ATX series, Shimadzu Corporation, Tokyo). Pea pod powder was incorporated at 10, 20 and 30\% level in the standardized formula of biscuits by substituting refined flour. Dough was prepared and rolled. Square pieces of $0.6 \mathrm{~cm}$ thickness were cut and baked at $180^{\circ} \mathrm{C}$ for $15 \mathrm{~min}$.

\section{Chemical analysis of pea pod powder}

Pea pod powder was analyzed for moisture, ash, protein and fat, according to the standard AACC methods [19]. Water activity was calculated using water activity meter (Model 4TE, Aqua Lab, Pullman, WA, USA).

\section{Evaluation of biscuits}

Physical properties of biscuits such as weight and thickness were determined by AACC, 1955 . The biscuits were evaluated for sensory attributes by panel of 10 semi- trained judges using 9-point hedonic scale. The biscuits were evaluated for color, appearance, aroma, texture and taste by the judges and mean of the scores for all the sensory characteristic was expressed as overall acceptability.

\section{Results and Discussion}

All formulations showed good dough handling characteristics, sheeting and cutting. Average weight and thickness of standard biscuit was 10 gram and $0.6 \mathrm{~cm}$ respectively. Figures $1-4$ shows biscuits prepared from composite flours.

\section{Chemical analysis of pea pod powder}

Nutritional composition of pea pod powder is given in Table 2. Data presented shows that main component was carbohydrate. Crude protein content of pea pod powder was estimated to be $14.88 \%$, which was found to be higher than reported by Aparicio et al. [22]. The results also showed that pea pod powder is rich in ash content which is $5 \%$ ash and higher than other vegetable waste like tomato peel fibre [12]. Our studies indicate low amount of crude fat making them healthier. Literature reports high amount of calcium in pea pods in comparison to by-products broad bean pod and okara [22]. The results indicate that pea pod powder is a good source of crude fibre with $7.86 \%$ content. The calcium, iron and zinc content computed is $0.83 \%, 0.83 \%$ and

\begin{tabular}{|c|c|}
\hline Ingredients & Quantity (\%) \\
\hline Composite flour & 100 \\
\hline Jaggery & 50 \\
\hline Fat & 50 \\
\hline Baking powder & 0.01 \\
\hline Milk & 0.2 \\
\hline
\end{tabular}

Table 1: Ingredients used in biscuit preparation.

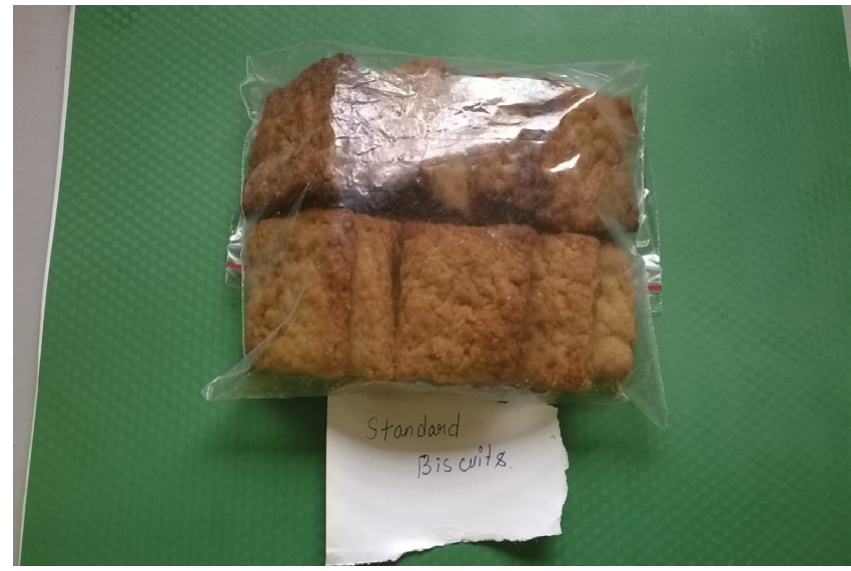

Figure 1: Standard biscuit (0\%Peapod powder).

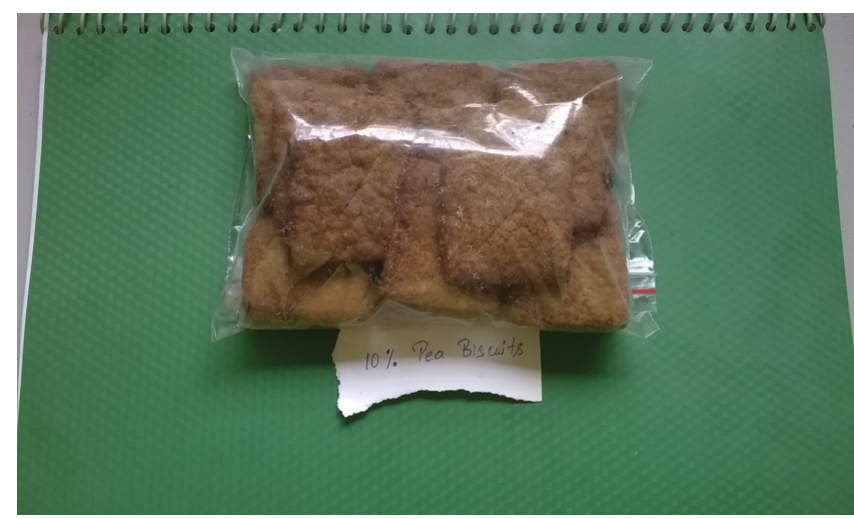

Figure 2: 10\% Peapod powder Biscuits.

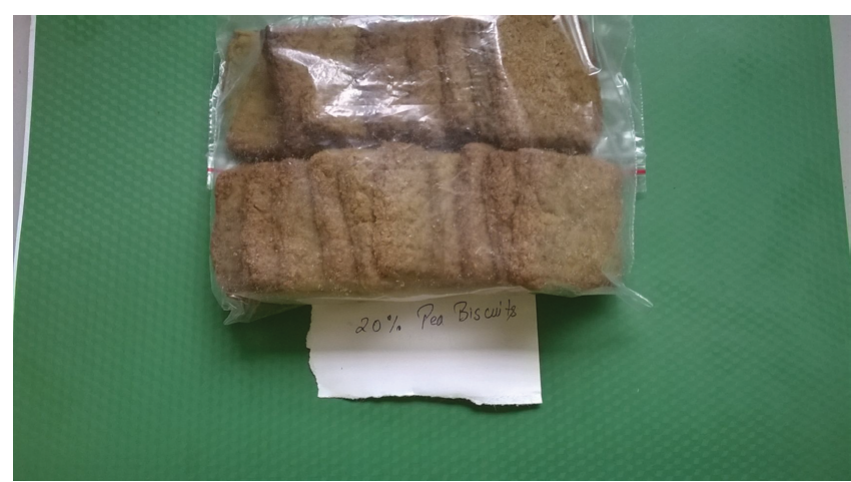

Figure 3: 20\% Peapod powder Biscuits.

$0.56 \%$, respectively which is in agreement with previous findings by Aparicio et al. [22]. Analysis confirms that pea pod powder has very good amount of minerals particularly iron.

\section{Physical evaluation of biscuits}

Biscuits prepared using $0 \%, 10 \%, 20 \%$ and $30 \%$ of pea peapod powder were evaluated for various physical and sensory characteristics. The thickness was slightly affected with increase in level of pea pod powder (Table 3). The thickness of biscuits incorporated with pea pod 
Citation: Garg M (2015) Nutritional Evaluation and Utilization of Pea Pod Powder for Preparation of Jaggery Biscuits. J Food Process Technol 6: 522. doi:10.4172/2157-7110.1000522

powder decreased from standard but highest thickness was observed with $20 \%$ pea pod powder. Further decease observed at 30\% level might be due to dilution of gluten, also reported by Ajila et al. [29].

\section{Sensory evaluation of biscuits}

Sensory evaluation of biscuits prepared by substituting wheat flour with pea pod powder is presented in Table 4 . The overall acceptability declined at $30 \%$ level. No significant difference was observed in color up till 20\% level of addition. The taste and flavor of biscuits improved on incorporation of pea pod powder at $20 \%$. Considering the parameters: color, appearance, aroma, texture and taste, it could be deduced that $20 \%$ level of incorporation of peapod powder was ideal.

\section{Influence of pea pod powder on water activity of biscuits}

At $30^{\circ} \mathrm{C}$, water activity of standard biscuits was $0.35,10 \%$ pea pod biscuits had $0.38,20 \%$ pea pod biscuits contained 0.42 and $30 \%$ biscuits had 0.46 water activity (Figure 5 ). This showed increased value of water activity on increasing the percentage of peapod powder. This also showed that product can be stored for long time at room temperature as it has low water activity.

\section{Conclusions}

This study illustrates the feasibility of producing powder rich in protein, minerals and dietary fibre from industry waste, pea pod. Pea

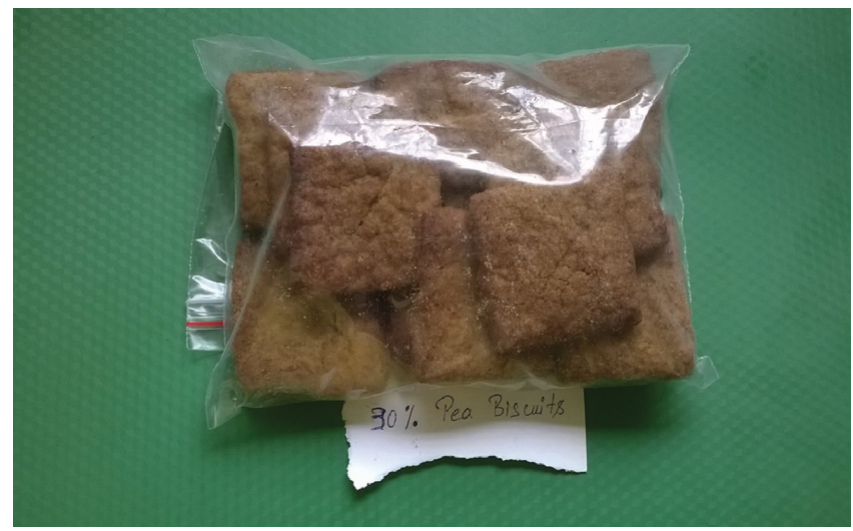

Figure 4: 30\% Peapod powder Biscuits

\begin{tabular}{|c|c|}
\hline Nutrient & Content $\mathbf{( g / 1 0 0 g}$ dry matter) \\
\hline Protein & $14.88 \pm 0.44$ \\
\hline Fat & $0.43 \pm 0.03$ \\
\hline Ash & $5 \pm 0.50$ \\
\hline Total carbohydrates & $61.43 \pm 0.03$ \\
\hline Crude fibre & $7.86 \pm 1.0$ \\
\hline Calcium & $0.83 \pm 0.03$ \\
\hline Iron & $0.83 \pm 0.08$ \\
\hline Zinc & $0.56 \pm 0.06$ \\
\hline Energy & $309.1 \mathrm{kcal}$ \\
\hline
\end{tabular}

Table 2: Nutritional composition $(\mathrm{g} / 100 \mathrm{~g})$ of pea pod po wder.

\begin{tabular}{|c|c|c|}
\hline Pea pod powder level (\%) & Weight $\mathbf{( g m})$ & Thickness $\mathbf{( c m})$ \\
\hline 0 (standard) & $10 \pm 1.00$ & $0.6 \pm 0.2$ \\
\hline 10 & $9.66 \pm 0.67$ & $0.55 \pm 0.09$ \\
\hline 20 & $11.06 \pm 0.45$ & $0.62 \pm 0.05$ \\
\hline 30 & $10.73 \pm 0.55$ & $0.61 \pm 0.04$ \\
\hline
\end{tabular}

Table 3: Physical characteristics of biscuits.

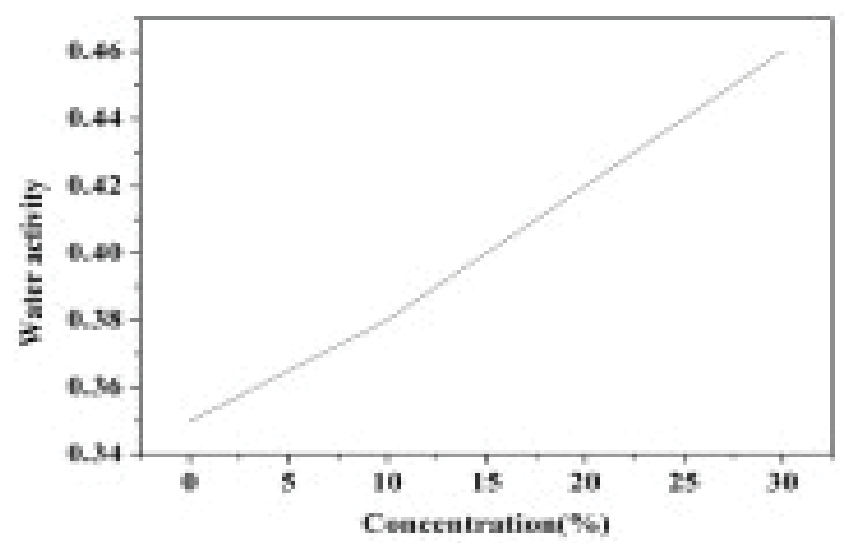

Figure 5: Graphical representation of water activity of pea pod powder.

\begin{tabular}{|c|c|c|c|c|c|c|}
\hline $\begin{array}{c}\text { Pea pod } \\
\text { powder level } \\
(\%)\end{array}$ & Color & Appearance & Aroma & Texture & Taste & $\begin{array}{c}\text { Overall } \\
\text { acceptability }\end{array}$ \\
\hline 0 & $7.1 \pm$ & $7 \pm 0.66$ & $6.2 \pm$ & $8 \pm 0.66$ & $7.2 \pm$ & $7 \pm 0.66$ \\
& 0.8 & & 0.63 & & 0.63 & \\
\hline 10 & $7.5 \pm$ & $7.6 \pm 0.84$ & $6.1 \pm$ & $7.2 \pm$ & $7.0 \pm$ & $7 \pm 0.66$ \\
& 1.08 & & 0.73 & 0.78 & 0.66 & \\
\hline 20 & $6.9 \pm$ & $8.1 \pm 0.73$ & $7.2 \pm$ & $7.0 \pm$ & $7.9 \pm$ & $7.9 \pm 0.56$ \\
& 0.73 & & 0.63 & 0.66 & 0.56 & \\
\hline 30 & $6.3 \pm$ & $6 \pm 0.66$ & $6.8 \pm$ & $6.1 \pm$ & $7.1 \pm$ & $6.1 \pm 0.73$ \\
& 0.48 & & 0.63 & 0.56 & 0.56 & \\
\hline
\end{tabular}

Table 4: Sensory characteristics of pea pod powder biscuits.

pod powder can be exploited to enhance the nutritive value of biscuits. Biscuits containing $20 \%$ pea pod powder were highly acceptable. Thus, it can be concluded that pea pods which otherwise are discarded in bins or used in animal feed can be used for value addition in various food.

\section{References}

1. Laufenberg G, Kunz B, Nystroem M (2003) Transformation of vegetable waste into value added products: $(A)$ the upgrading concept; $(B)$ practical implementations. Bioresource Technol 87: 167-198.

2. Peschel W, Rabaneda FS, Diekmann W, Plescher A, Gartzía I, et al. (2006) An industrial approach in the search of natural antioxidants from vegetable and fruit wastes. Food Chem 97: 137-150.

3. Shea NO, Arendt EK, Gallagher E (2012) Dietary fibre and phytochemical characteristics of fruit and vegetable by-products and their recent applications as novel ingredients in food products. Innov Food Sci Emerg Technol 16: 1 -10.

4. Stajčić S, Ćetković G, Brunet JC, Djilas S, Mandić A, et al. (2015) Tomato waste: Carotenoids content, antioxidant and cell growth activities. Food Chem 172: $225-232$.

5. Babbar N, Oberoi HS, Uppal DS, Patil RT (2011) Total phenolic content and antioxidant capacity of extracts obtained from six important fruit residues. Food Res In 44: 391 -396.

6. Massias A, Boisard S, Baccaunaud M, Calderon FL, Paternault PS, et al. (2015) Recovery of phenolics from apple peels using $\mathrm{CO}_{2}+$ ethanol extraction Kinetics and antioxidant activity of extracts. J Supercrit Fluids 98: 172 -182.

7. Amado IR, Franco D, Sánchez M, Zapata C, Vázquez JA, et al. (2014) Optimisation of antioxidant extraction from Solanum tuberosum potato peel waste by surface response methodology. Food Chem 165: 290 -299

8. Chantaro P, Devahastin S, Chiewchan N (2008) Production of antioxidant high dietary fiber powder from carrot peels. Food Sci Technol 41: 1987-1994.

9. Nilnakara S, Chiewchan N, Devahastin S (2009) Production of antioxidant dietary fibre powder from cabbage outer leaves. Food Bioprod Processc 87: $301-307$. 
Citation: Garg M (2015) Nutritional Evaluation and Utilization of Pea Pod Powder for Preparation of Jaggery Biscuits. J Food Process Technol 6: 522. doi:10.4172/2157-7110.1000522

10. Arora A, Camire ME (1994) Performance of potato peels in muffins and cookies. Food Res Int 27: 15-22.

11. Stojceska V, Ainsworth P, Plunkett A, İbanoğlu E, İbanoğlu S, et al. (2008) Cauliflower by-products as a new source of dietary fibre, antioxidants and proteins in cereal based ready-to-eat expanded snacks. J Food Eng 87: 554563.

12. González IN, Valverde VG, Alonso JG, Periago MJ (2011) Profile, functional and antioxidant properties of tomato peel fiber. Food Res Int 44: 1528-1535.

13. Rizk EM , El-Kady AT, El-Bialy AR (2014) Characterization of carotenoids (lyco-red) extracted from tomato peels and its uses as natural colorants and antioxidants of ice cream. Ann Agri Sci 59: 53-61.

14. Elbadrawy E, Sello A (2011) Evaluation of nutritional value and antioxidant activity of tomato peel extracts. Arab J Chem.

15. FAO Statistical yearbook (2013) Food and Agriculture Organization of the United Nations, Rome, Italy.

16. Sharma R, Rawat R, Bhogal RS, Oberoi HS (2015) Multi-component thermostable cellulolytic enzyme production by Aspergillus niger $\mathrm{HN}-1$ using pea pod waste: Appraisal of hydrolytic potential with lignocellulosic biomass. Process Biochem 50: 696-704.

17. Wadhwa M, Kaushal S, Bakshi MPS (2006) Nutritive evaluation of vegetable wastes as complete feed for goat bucks. Small Ruminant Res 64: 279-284.

18. Wadhwa M, Bakshi MPS (2005) Vegetable wastes - a potential source of nutrients for ruminants. Indian J Anim Nutr 22: 70-76.

19. AACC (1995) Approved methods of the American Association of Cereal Chemists (9th eds). AACC International.

20. Garg, M, SharmaS, Varmani GS, Sadhu DS (2014) Drying kinetics of thin layer pea pods using tray drying. Int J Food Nutr 3: 61-66.
21. Gupta R, Chauhaun TR, Lall D (1993) Nutritional potential of vegetable waste products for ruminants. Bioresource Technol 44: 263-265

22. Aparicio IM, Cuenca AR, Suárez MJV, Revilla MAZ, Sanz MDT, et al. (2010) Pea pod, broad bean pod and okara, potential sources of functional compounds. Food Sci Technol 43: 1467-1470.

23. Umesha SS, Manohar RS, Indiramma AR, Akshitha S, Naidu KA, et al. (2015) Enrichment of biscuits with microencapsulated omega- 3 fatty acid (Alphalinolenic acid) rich Garden cress (Lepidium sativum) seed oil: Physical, sensory and storage quality characteristics of biscuits. Food Sci Technol 62: 654-661.

24. Tyagi SK, Manikantan MR, Oberoi HS, Kaur G (2007) Effect of mustard flour incorporation on nutritional, textural and organoleptic characteristics of biscuits. J Food Eng 80: 1043-1050.

25. Kaur M, Sandhu KS, Arora AP, Sharma A (2015) Gluten free biscuits prepared from buckwheat flour by incorporation of various gums: Physicochemical and sensory properties. Food Sci Technol 62: 628-632.

26. Vujić L, Čepo DV, Dragojević IV (2015) Impact of dietetic tea biscuit formulation on starch digestibility and selected nutritional and sensory characteristics. Food Sci Technol 62: 647-653.

27. Hooda S, Jood S (2005) Organoleptic and nutritional evaluation of wheat biscuits supplemented with untreated and treated fenugreek flour. Food Chem 90: 427-435.

28. Reddy V, Urooj A, Kumar A (2005) Evaluation of antioxidant activity of some plant extracts and their application in biscuits. Food Chem 90: 317-321.

29. Ajila CM, Leelavathi K, Prasada Rao UJS (2008) Improvement of dietary fiber content and antioxidant properties in soft dough biscuits with the incorporation of mango peel powder. 